\title{
Human protein $C$ concentrate in the treatment of purpura fulminans: a retrospective analysis of safety and outcome in 94 pediatric patients
}

\author{
Alex Veldman ${ }^{*}$, Doris Fischer ${ }^{2}$, Flora Y Wong ${ }^{1}$, Wolfhart Kreuz ${ }^{2}$, Michael Sasse ${ }^{3}$, Bruno Eberspächer ${ }^{4}$, \\ Ulrich Mansmann ${ }^{5}$, Rudolf Schosser ${ }^{4}$
}

\begin{abstract}
Introduction: Purpura fulminans (PF) is a devastating complication of uncontrolled systemic inflammation, associated with high incidence of amputations, skin grafts and death. In this study, we aimed to clarify the clinical profile of pediatric patients with PF who improved with protein C (PC) treatment, explore treatment effects and safety, and to refine the prognostic significance of protein $C$ plasma levels.

Methods: In Germany, patients receiving protein C concentrate (Ceprotin ${ }^{\oplus}$, Baxter AG, Vienna, Austria) are registered. The database was used to locate all pediatric patients with PF treated with PC from 2002 to 2005 for this national, retrospective, multi-centered study.

Results: Complete datasets were acquired in 94 patients, treated in 46 centers with human, non-activated protein C concentrate for purpura fulminans. PC was given for 2 days (median, range 1-24 days) with a median daily dose of $100 \mathrm{IU} / \mathrm{kg}$. Plasma protein C levels increased from a median of $27 \%$ to a median of $71 \%$ under treatment. $22.3 \%$ of patients died, $77.7 \%$ survived to discharge. Skin grafts were required in $9.6 \%$, amputations in $5.3 \%$. PF recovered or improved in $79.8 \%$, remained unchanged in $13.8 \%$ and deteriorated in $6.4 \%$. Four adverse events occurred in 3 patients, none classified as severe. Non-survivors had lower protein $C$ plasma levels $(P<0.05)$ and higher prevalence of coagulopathy at admission $(P<0.01)$. Time between admission and start of $P C$ substitution was longer in patients who died compared to survivors $(P=0.03)$.

Conclusions: This retrospective dataset shows that, compared to historic controls, only few pediatric patients with PF under PC substitution needed dermatoplasty and/or amputations. Apart from epistaxis, no bleeding was observed. Although the data comes from a retrospective study, the evidence we present suggests that PC had a beneficial impact on the need for dermatoplasty and amputations, pointing to the potential value of carrying out a prospective randomised controlled trial.
\end{abstract}

\section{Introduction}

Dermal and systemic thrombosis of the microcirculation, referred to as purpura fulminans (PF), is a devastating complication of widespread endothelial destruction due to uncontrolled systemic inflammation, associated with a high incidence of multiple organ failure, need for amputations, skin grafts and death. PF most frequently occurs in the pediatric age group, with a peak incidence in

\footnotetext{
* Correspondence: alex.veldman@monash.edu

'Monash Newborn, Monash Medical Centre; The Ritchie Centre, Monash Institute for Medical Research and Department of Pediatrics, Monash University, 246 Clayton RD, Clayton 3168, Melbourne, Australia Full list of author information is available at the end of the article
}

infants ( 1 to 3 years of age) and adolescents (16 to 18 years of age). Although most frequently seen in the context of severe septic shock, in particular in patients with meningococcemia, PF also occurs in the rare scenario of homozygous or double heterozygous protein $\mathrm{C}$ (PC) deficiency [1]. Indeed, the clinical manifestation of a severe $\mathrm{PC}$ deficiency in the form of PF has resulted in the description of PF as the clinical symptom of an acute PC pathway failure [2]. Consequently, many intensivists have used PC substitution in patients with PF, mostly with promising results [3-6]. The biological rationale for this use was the anti-coagulant, anti-inflammatory, 
pro-fibrinolytic, anti-apoptotic and barrier enhancing action of PC [7-10].

This retrospective multi-centered study analyzes clinical features, safety and outcome in 94 pediatric and adolescent patients with PF who received a human nonactivated PC concentrate as rescue therapy in Germany from 2002 to 2005. In this study, we aimed to clarify the clinical profile of pediatric patients with PF who improved with PC treatment, explore treatment effects and safety, and to refine the prognostic significance of PC plasma levels. Finally, this study will help to establish hypotheses and endpoints for future prospective studies on human PC in patients with PF.

\section{Materials and methods}

The ethics committee of the J.W. Goethe University, Frankfurt, Germany, approved the study protocol for this retrospective, multi-center study. Patients who received a human plasma-derived, virus-inactivated PC concentrate (Ceprotin' Baxter AG, Vienna, Austria) in Germany were registered by the manufacturer due to a post-marketing commitment requested by the European Medicines Agency. This German database was used to locate all pediatric patients treated with PC concentrate from 2002 to 2005 . The flow of the patients throughout the study is displayed in Figure 1. If a patient who received $\mathrm{PC}$ concentrate was identified, the principal investigator contacted the treating physician with an invitation to participate in the study. If the treating physician agreed to participate, the hospital was visited by a medical monitor (physician) for standardized (form-based clinical reporting) data collection. For analysis, patients were stratified into three outcome groups by survival to hospital discharge and complications (negative outcome $=$ death and/or amputation; intermediate outcome $=$ survival with skin grafts/dermatoplasty; positive outcome $=$ survival without amputations or skin grafts). As data were collected on anonymous forms, the ethics committee waived the need for informed consent by the patient or relatives.

\section{Statistics}

Descriptive statistics were used for categorical (tables, rates, $95 \%$ confidence intervals $(\mathrm{CI})$ ) and continuous (quartiles, minimum, maximum, mean, standard deviation) variables. Differences in categorical variables between groups were tested by the chi-square test. Differences in continuous variables between groups were tested by the non-parametric Mann-Whitney U test. Comparisons of relevant parameters were performed between survivors and non-survivors. The relevance of PC plasma levels at admission on the probability to survive the disease was assessed by a logistic regression and an odds ratio was calculated to quantify the influence of the level of PC plasma activity at admission on survival to discharge.

\section{Results}

\section{Demographics}

Of the 102 patients located, 94 entered the final analysis (Figure 1): 52 (55.3\%) were male and 42 (44.7\%) female; 8 (8.9\%) were newborn (<28 days old), 36 (38.3\%) were

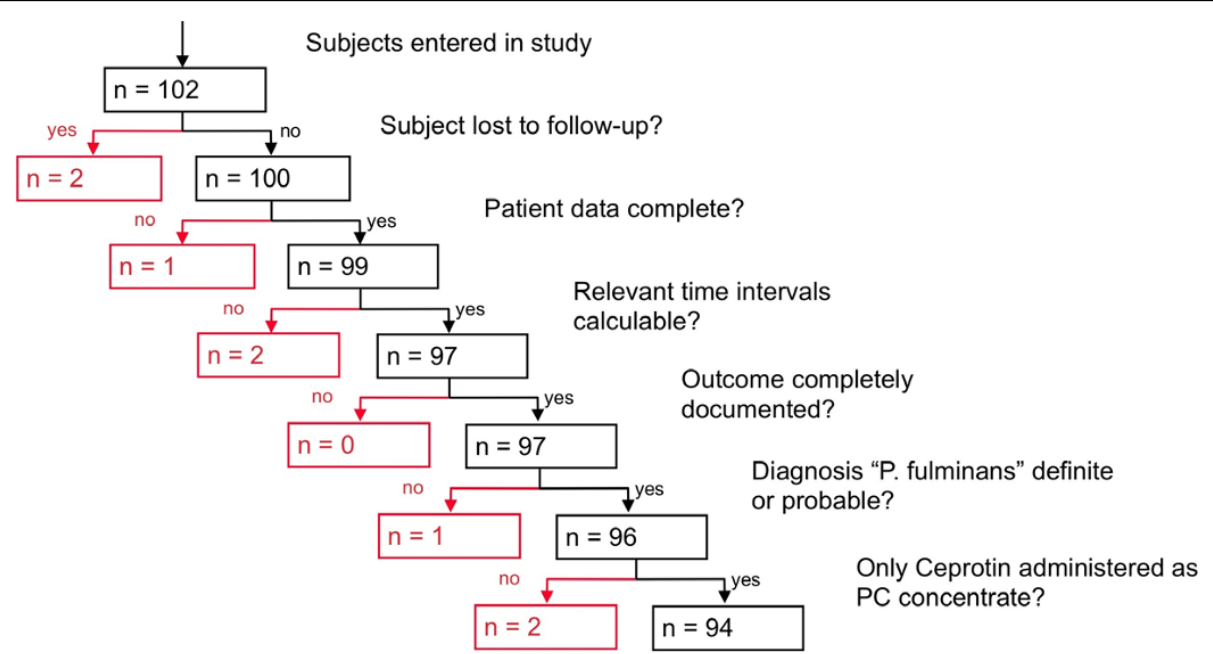

Figure 1 Flow of patients through the study and exclusions of patients. The diagnosis of purpura fulminans (PF) was regarded as definite in the presence of livid to partly necrotic lesions of irregular shape and with sharp, clearly defined borders with either rapid progression or already ubiquitous appearance. The diagnosis of PF was regarded as probable in the presence of livid to partly necrotic lesions of irregular shape and with sharp, clearly defined borders. The diagnosis of PF was regarded as unclear in the presence of just livid to partly necrotic lesions without any of the other criteria. The diagnosis of PF was not confirmed in any patient with lesions not fulfilling the above defined criteria. PC, protein C. 
infants (28 days to 2 years), 29 (30.9\%) were children ( 2 to 12 years) and 21 (22.3) were adolescents (12 to 18 years).

Patients were treated in 46 different centers, with 36 centers treating 2 or less patients and 10 centers treating 3 or more patients. None of the centers participated in or recruited pediatric patients for treatment studies with activated PC at the time of this study.

\section{Origin of $\mathrm{PF}$}

PF was the result of acquired sepsis rather than congenital PC deficiency in all patients. Neisseria meningitides was isolated in 75 (79.8\%) patients, in 52 of those whose sero-groups were specified.

\section{Survival and outcome of PF}

Twenty-one (22.3\%) patients died at a mean duration of two days, and $73(77.7 \%)$ patients survived to discharge. There was no significant difference in age or gender between survivors and patients who did not survive. Skin grafts were required in nine $(9.6 \%)$ and amputations in five (5.3\%) patients.

PF recovered or improved in 75 (79.8\%) patients, remained unchanged in $13(13.8 \%)$ patients and deteriorated in $6(6.4 \%)$ patients.

\section{Shock}

At admission, no difference in mean arterial pressure was detected between survivors and non-survivors (median 61.5 vs. $70 \mathrm{mmHg}, P=0.168$ ). However, already at admission, survivors presented with lower heart rates (median 150 vs. $185 \mathrm{bpm}, P=0.0132$ ) higher Glasgow coma scale scores (mean 12.5 vs. 9.9, $P=0.027$ ) and less negative base excess compared with non-survivors (median -4.95 vs. $-11.85 \mathrm{mmol} / \mathrm{l}, P=0.021$ ).

A total of 63 patients received inotropic support for a median duration of two days.

\section{Protein C treatment}

Non-survivors had significantly lower PC plasma activity at admission than survivors (median 10 vs. $30 \%, P=$ 0.011 ). A higher level of PC plasma activity by $1 \%$ at admission improved the odds to survive significantly $(P=0.0285)$ by a factor of $1.06(95 \% \mathrm{CI}$ for odds ratio $=$ 1.01 to 1.12). PC was given for a median of 33 hours (range 1 to 645 hours) with a median daily dose of 100 $\mathrm{IU} / \mathrm{kg}$ (range 28 to $375 \mathrm{IU} / \mathrm{kg}$ ). PC was administered as a bolus every four to six hours in 78 patients, and as an initial bolus followed by continuous infusion in the remaining 16 patients. There was no significant difference in survival between the bolus group ( $21.8 \%$ died) and the bolus plus infusion group $(25.0 \%$ died; $P=0.961$ ). Plasma PC levels increased from a median of $27 \%$ (range 1 to $75 \%$ ) prior to $\mathrm{PC}$ treatment to a median of $71 \%$ under treatment (range 14 to $184 \%$, Table 1 ). Once under PC substitution, there was no significant difference in plasma PC levels between survivors and non-survivors $(P=0.605)$.

The time interval between admission and the start of PC substitution was significantly longer (median 8.6 vs. 4 hours, $P=0.03$ ) in patients who died compared with those who survived, and also longer in patients who had amputations and/or died compared with those who fully recovered (median 9.25 vs. 4 hours, $P=0.016$ ).

\section{Inflammatory response}

C-reactive protein (CRP) levels were significantly lower at admission in non-survivors compared with survivors (Median: 5.9 vs. $11.6 \mathrm{mg} / \mathrm{dl}, P=0.002$ ). White blood cell counts were also lower on admission and during treatment in the non-survivors, but this trend did not reach statistical significance (Table 1 ).

\section{Coagulopathy}

Non-survivors showed a significantly higher prevalence than survivors of coagulopathy with prolonged activated partial thromboplastin time (aPTT) at admission (median: 108 vs. 52 seconds, $P<0.0001$ ). A significantly higher rate of coagulopathy was still documented with PC treatment in the non-survivors (Table 1). The platelet count did not differ significantly at admission between survivors and non-survivors; however, during treatment, survivors showed significantly higher platelet counts than patients who died (median: 103 vs. $61 \mathrm{G} / \mathrm{l}, P=0.0047$ ).

\section{Fresh frozen plasma}

Of the 94 patients, 71 received fresh frozen plasma (FFP): $45 \%$ received one FFP transfusion, $30 \%$ two and $25 \%$ received three or more FFP transfusions. The total amount of FFP given was $33.3 \mathrm{ml} / \mathrm{kg}$ in patients being transfused, on day one a median of $20 \mathrm{ml} / \mathrm{kg}$, on day two a median of $22 \mathrm{ml} / \mathrm{kg}$ and on day three a median of $13 \mathrm{ml} / \mathrm{kg}$. There was no difference in survival between those patients transfused compared with those who did not receive FFP $(P=0.345)$. However, there was a trend towards a better survival in those patients receiving high volume ( $\geq 25 \mathrm{ml} / \mathrm{kg} / \mathrm{d}$ ) FFP on day one compared with those who received less or no FFP $(P=0.069)$.

\section{Length of stay and mechanical ventilation}

Length of stay on the ICU was a median of eight days ( 1 to 95 days) in the whole group, a median of two days for non-survivors and a median of nine days for survivors $(P<0.0001)$. The duration of mechanical ventilation was a median of 6.5 days for those who survived. Survivors were discharged out of hospital after a median of 18 days, and non-survivors had a median hospital stay of 2 days. 
Table 1 Clinical and laboratory parameters of all patients, survivors, non-survivors before and during treatment with protein C concentrate

\begin{tabular}{|c|c|c|c|c|}
\hline & All & $\begin{array}{l}\text { Survived } \\
(n=73)\end{array}$ & $\begin{array}{c}\text { Died } \\
(n=21)\end{array}$ & $P$ \\
\hline $\begin{array}{l}\text { Male/female } \\
\text { (n) }\end{array}$ & $52 / 42$ & $42 / 31$ & $10 / 11$ & n.s. \\
\hline $\begin{array}{l}\text { Age } \\
\text { (years) }\end{array}$ & 2.46 & 2.93 & 1.69 & n.s. \\
\hline \multicolumn{5}{|l|}{ PC treatment } \\
\hline $\begin{array}{l}\text { PC total dose } \\
\text { (IU/kg) }\end{array}$ & $258.8(127.6-410.9)$ & $277.8(132.4-444.4)$ & $153.8(126.0-375.0)$ & n.s. \\
\hline $\begin{array}{l}\text { PC daily dose } \\
\text { (IU/kg/d) }\end{array}$ & $100(73.4-136.6)$ & $\begin{array}{c}100 \\
(78.74-133.3)\end{array}$ & $81.08(71.09-153.8)$ & n.s. \\
\hline PC therapy duration (d) & $\begin{array}{c}2 \\
(1-4)\end{array}$ & $\begin{array}{c}3 \\
(2-4)\end{array}$ & $\begin{array}{c}2 \\
(1-4)\end{array}$ & n.s. \\
\hline $\begin{array}{l}\text { Bolus/ } \\
\text { Bolus + cont. inf. }\end{array}$ & $78 / 16$ & $61 / 12$ & $17 / 4$ & n.s. \\
\hline \multicolumn{5}{|c|}{ Haematological paramenters prior to PC treatment } \\
\hline $\begin{array}{l}\text { WBC } \\
\text { (pl) }\end{array}$ & $\begin{array}{c}10.4 \\
(5.0-17.02)\end{array}$ & $\begin{array}{c}11.3 \\
(5.3-18.7)\end{array}$ & $\begin{array}{c}7.21 \\
(4.6-10.75)\end{array}$ & n.s $(0.062)$ \\
\hline $\begin{array}{l}\text { CRP } \\
(\mathrm{mg} / \mathrm{dl})\end{array}$ & $\begin{array}{c}10.48 \\
(5.65-16.47)\end{array}$ & $\begin{array}{c}11.6 \\
(7.81-17.31)\end{array}$ & $\begin{array}{c}5.9 \\
(1.99-8.92)\end{array}$ & 0.0018 \\
\hline $\begin{array}{l}\text { Platelets } \\
\text { (G/I) }\end{array}$ & $\begin{array}{c}110 \\
(66-183)\end{array}$ & $\begin{array}{c}116 \\
(74-182)\end{array}$ & $\begin{array}{c}78 \\
(52-178)\end{array}$ & n.s. \\
\hline $\begin{array}{l}\text { PT } \\
\text { (\%) }\end{array}$ & $\begin{array}{c}41 \\
(32-54)\end{array}$ & $\begin{array}{c}44 \\
(33-56)\end{array}$ & $\begin{array}{c}31 \\
(22-36)\end{array}$ & $<0.001$ \\
\hline $\begin{array}{l}\text { aPTT } \\
\text { (sec.) }\end{array}$ & $\begin{array}{c}59 \\
(43-91)\end{array}$ & $\begin{array}{c}52 \\
(39-71)\end{array}$ & $\begin{array}{c}108 \\
(81-160)\end{array}$ & $<0.001$ \\
\hline $\begin{array}{l}\text { Fibrinogen } \\
\text { (mg/dl) }\end{array}$ & $\begin{array}{c}270 \\
(174-440)\end{array}$ & $\begin{array}{c}347 \\
(217-503)\end{array}$ & $\begin{array}{c}129 \\
(82-202)\end{array}$ & $<0.001$ \\
\hline $\begin{array}{l}\text { D-Dimers } \\
\text { (mg/l) }\end{array}$ & $\begin{array}{c}2.38 \\
(0.93-8.99)\end{array}$ & $\begin{array}{c}2.13 \\
(0.89-8.62)\end{array}$ & $\begin{array}{c}6.40 \\
(1.08-12.00)\end{array}$ & n.s. \\
\hline $\begin{array}{l}\text { AT } \\
(\%)\end{array}$ & $\begin{array}{c}76 \\
(57-87)\end{array}$ & $\begin{array}{c}80 \\
(60-88)\end{array}$ & $\begin{array}{c}70 \\
(46-80)\end{array}$ & n.s. \\
\hline $\begin{array}{l}\text { PC } \\
\text { (\%) }\end{array}$ & $\begin{array}{c}27 \\
(14-39)\end{array}$ & $\begin{array}{c}30 \\
(18-41)\end{array}$ & $\begin{array}{c}10 \\
(10-18)\end{array}$ & $<0.05$ \\
\hline \multicolumn{5}{|c|}{ Haematological parameters during PC treatment } \\
\hline $\begin{array}{l}\text { WBC } \\
\text { (pl) }\end{array}$ & $\begin{array}{c}21.25 \\
(12.75-27.28)\end{array}$ & $\begin{array}{c}23.65 \\
(13.65-28.75)\end{array}$ & $\begin{array}{c}16.35 \\
(7.7-20.90)\end{array}$ & $<0.05$ \\
\hline $\begin{array}{l}\text { CRP } \\
(\mathrm{mg} / \mathrm{dl})\end{array}$ & $14.70(7.0-21.8)$ & $\begin{array}{c}15.91 \\
(7.1-23.64)\end{array}$ & $\begin{array}{c}9.36 \\
(6.90-15.88)\end{array}$ & n.s. \\
\hline $\begin{array}{l}\text { Platelets } \\
\text { (G/I) }\end{array}$ & $\begin{array}{c}96 \\
(57-130)\end{array}$ & $\begin{array}{c}103 \\
(65.5-136.5)\end{array}$ & $\begin{array}{c}61 \\
(30-80.75)\end{array}$ & $<0.01$ \\
\hline $\begin{array}{l}\text { PT } \\
(\%)\end{array}$ & $\begin{array}{c}69 \\
(48.5-87)\end{array}$ & $\begin{array}{c}77.8 \\
(55-91)\end{array}$ & $\begin{array}{c}45.5 \\
(37.75-55.75)\end{array}$ & $<0.01$ \\
\hline $\begin{array}{l}\text { aPTT } \\
\text { (sec.) }\end{array}$ & $\begin{array}{c}43 \\
(33-52.75)\end{array}$ & $\begin{array}{c}41 \\
(33-47)\end{array}$ & $\begin{array}{c}61 \\
(47.5-88.4)\end{array}$ & $<0.01$ \\
\hline $\begin{array}{l}\text { Fibrinogen } \\
\text { (mg/dl) }\end{array}$ & $\begin{array}{c}558.5 \\
(342-747.2)\end{array}$ & $\begin{array}{c}600.5 \\
(418-766)\end{array}$ & $\begin{array}{c}214.5 \\
(184-299.2)\end{array}$ & $<0.01$ \\
\hline $\begin{array}{l}\text { D-Dimers } \\
(\mathrm{mg} / \mathrm{l})\end{array}$ & $\begin{array}{c}1.95 \\
(0.8-6.16)\end{array}$ & $\begin{array}{c}1.6 \\
(0.68-5.96)\end{array}$ & $\begin{array}{c}2.93 \\
(1.14-6.4)\end{array}$ & n.s. \\
\hline $\begin{array}{l}\text { AT } \\
(\%)\end{array}$ & $\begin{array}{c}87 \\
(68.5-102.2)\end{array}$ & $\begin{array}{c}87 \\
(68-101.5)\end{array}$ & $\begin{array}{c}78 \\
(70-102)\end{array}$ & n.s. \\
\hline $\begin{array}{l}\text { PC } \\
\text { (\%) }\end{array}$ & $\begin{array}{c}71 \\
(53.5-108.4)\end{array}$ & $\begin{array}{c}79 \\
(54.7-106.8)\end{array}$ & $\begin{array}{c}68.5 \\
(33.75-108.5)\end{array}$ & n.s. \\
\hline
\end{tabular}

Data on patient characteristics, outcome and laboratory findings. Shown as median and inter-quartile range (range between first and third quartile). Note that not all laboratory parameters could be obtained in all patients at each time-point.

aPT, activated partial thromboplastin time; AT, antithrombin; CRP, C reactive protein; n.s., not significant; PC, protein C; PT, prothrombin time; WBC, white blood cell count. 


\section{Adverse events and hemorrhage}

Four adverse events were reported in three patients. None was classified as severe by the treating physician (two events of hemorrhage from nose and/or throat, one event of pleural effusion, one event of transient increase in body temperature). The first patient with an adverse event developed bleeding from the nose six hours after receiving $66 \mathrm{IU} / \mathrm{kg}$ PC. The bleeding stopped spontaneously after one hour and the patient received the next scheduled dose two hours after the onset of the event without further complications. The treating physician classified the severity as moderate and causative relation to PC treatment as unknown. The second patient was a severely coagulopathic child, who developed hemorrhage from the throat and nose immediately after a difficult endo-tracheal intubation approximately 13 hours after receiving $83 \mathrm{IU} / \mathrm{kg} \mathrm{PC}$. The patient received the next dose as scheduled four hours after the event without further complications. The same patient developed a pleural effusion (serious with later blood staining) more that 24 hours after the PC therapy was ceased. The treating physician classified the severity of both events as moderate, a causative relation to PC treatment as unlikely. A third patient showed a transient (10 minutes) and minor increase in body temperature (from $39.0^{\circ} \mathrm{C}$ to $39.5^{\circ} \mathrm{C}$ ) shortly after receiving $100 \mathrm{IU} / \mathrm{kg}$ PC. No treatment was required; the treating physician classified the severity as mild.

\section{Discussion}

Here we report what is to date the largest series of pediatric patients with PF, as a consequence of acute PC pathway failure in sepsis, treated with $\mathrm{PC}$ concentrate. In the majority of patients, the underlying infection was identified as meningococcemia. PC substitution was well tolerated, safe and the need for amputations and skin grafts with $5.3 \%$ and $9.6 \%$, respectively, both markedly lower than previously reported in children with PF.

$\mathrm{PF}$, if associated with septic shock, is a devastating disease carrying a high mortality and significant morbidity. Although improvement in health care delivery for these very sick patients has dramatically improved survival in recent years [11,12], permanent disability as a result of amputation of limbs or digits, extensive scarring, or neurological injury remains problematic. Gurgey and colleagues reported a series of 16 children; nine (69\%) of the 13 children aged 4 years or younger and one of the older children (age range $9-12$ years) (33\%) required amputation [13]. A case series by Wheeler and colleagues on 21 patients reported amputations in nine (43\%) patients [14]. Recent data from Rotterdam reports amputations in $8 \%$, skin grafts in $16 \%$ and skin scarring in $48 \%$ of survivors of meningococcal disease with PF, combined with orthopedic sequelae in $14 \%$ [15]. These patients did not receive PC. In five patients treated in a burn center including therapy with activated PC, an impressive $100 \%$ survival was achieved; however, amputations were still needed in two of the five children (40\%) [16].

We and others have previously described replacement therapy with human, non-activated PC in patients with meningococcemia in case reports and smaller case series [3,4,6,17-19]. Other studies have explored the use of activated PC in patients with PF. Vincent and colleagues published a post-hoc analysis of recent studies using activated PC in adult and pediatric patients with severe sepsis, presenting with PF, meningitis or meningococcal disease [5]. The authors identified 119 pediatric patients suitable for the analysis, 87 of them with PF. In that group, which had a comparable incidence of coagulopathy and low PC plasma levels, but a slightly more severe thrombocytopenia compared with the group reported here $(85 ; 42$ to 122 vs. $110 ; 66$ to 183 G/l median; first to third quartile), serious bleeding events were noticed in two patients during the infusion and in six patients over a 28 -day period. Fourteen-day mortality was $9.4 \%$, which is probably lower than the $22.3 \%$ in-hospital mortality in the group reported here. It is difficult to compare the illness severity of these two groups, because Vincent and colleagues did not report the rates for amputation or skin grafts. Another study, investigating the use of activated PC in children with severe sepsis, which was terminated prematurely due to lack of efficacy, showed an increased rate of hemorrhage in the activated PC compared with the placebo group, especially in children younger than 60 days [20].

In contrast, significant bleeding complications were not seen in our large group of pediatric patients and have also not been associated with the use of human, non-activated PC concentrate in adult studies so far.

As published previously, this study confirmed low plasma PC levels to be associated with negative outcome [21]. In fact, even a difference as small as $1 \%$ in PC plasma activity at admission changed the odds of survival significantly. For a number of medical conditions, minimizing the amount of time from patient presentation to initiation of treatment represents an important consideration in the improvement of treatment outcomes. Analysis of a large, hospital-level database suggested that earlier treatment with activated PC is associated with a lower in-hospital mortality in patients $(n=1179)$ with severe sepsis [22]. Another retrospective study, analyzing adults with severe sepsis and APC treatment found an increase in mortality from 33\% if treated on the day of diagnosis to $40 \%$ if treatment was delayed by one day and to $52 \%$ if treatment was delayed by two days or more [23]. In our analysis, the interval between admission to ICU and the commencement of PC 
replacement therapy was significantly longer in patients who died compared with those who survived, which may point towards the benefits of early therapy in this rapidly progressive condition.

During PC therapy, coagulatory and inflammatory markers may be important prognostic markers. The prevalence of ongoing coagulopathy, as reflected in a significantly more abnormal aPTT and prothrombin time, and in significantly lower fibrinogen levels at admission and during therapy, was higher in non-survivors compared with survivors. During therapy, but not at admission, platelets were found to be significantly lower in patients who did not survive, also pointing towards ongoing coagulopathy as a negative prognostic marker. Interestingly, although non-survivors showed lower PC plasma levels and higher incidence of coagulopathy, the inflammatory response in terms of CRP levels and leukocytosis was less marked in the non-survivors, which could imply a degree of immuno-paralysis in those patients.

Being a retrospective multi-center analysis, the limitations of this study are obvious: the lack of a control group and a prospective design makes it impossible to comment of the effects of PC on survival. The patients were treated in many different centers with a consequently large potential for intra-observer variability. On the other hand, the fact that even with so many different centers and protocols involved, the safety profile was still favorable in this unselected high-risk population is very encouraging.

\section{Conclusions}

This study shows encouragingly low rates of amputations and skin grafts in a large group of pediatric patients with PF, combined with improvement or resolution of PF in most of the patients across all pediatric age groups, with no significant adverse side effects. Our study supports the biological rationale of human nonactivated PC concentrate as a treatment for severe acquired PC deficiency, presenting with PF. Future studies investigating the effect of human, non-activated PC concentrate should focus on the potential benefit of early PC therapy in PF, and amputations and skin grafts as important outcome measures in this condition, which, despite recent advances in mortality control, still carries a high risk of disabling long-term morbidity.

\section{Key messages}

- Low plasma levels of PC are negatively correlated with survival in patients with PF in the context of meningococcemia.

- In this group of pediatric patients, substitution with human, non-activated PC concentrate resulted in an improvement of PF in the majority of patients, without causing significant bleeding.

- The need for amputations and skin grafts was low compared with historical controls, but there was no obvious effect on mortality.

- Future studies investigating the effect of human, non-activated PC concentrate should focus on early PC therapy in PF, with amputations and skin grafts as important outcome parameters.

\section{Abbreviations}

aPTT: activated partial thromboplastin time; Cl: confidence interval; CRP: C reactive protein; FFP: fresh frozen plasma; PC: protein C; PF: purpura fulminans.

\section{Acknowledgements}

We would like to thank Dr. K.H. Jünemann for his valuable efforts in data collection. Baxter Deutschland $\mathrm{GmbH}$, Heidelberg, Germany, financially supported this study.

The protein C study group: Dr. med. J. Urban, Kinderkrankenhaus Josefinum, Augsburg; Dr. med. S. Spieler, Kreiskrankenhaus, Bad Hersfeld; Dr. med. V. Varnholt, Charite/Virchow Krankenhaus, Berlin; Fr. Dr. med. U. Brosch, Vivantes Klinikum, Berlin; Dr. med. K. Bunke, Helios Kliniken Berlin Buch, Berlin; Dr. med. H. Schwalm, Klinikum Bremen-Mitte, Bremen; Dr. med. M. Rachold, ZKH Bremen -Nord, Bremen; Dr. med. Schlicht, Allgemeines Krankenhaus, Celle; Dr. med. W. Schäfer, Allgemeines Krankenhaus Hagen, Hagen; Fr. Dr. med. S. Griethe, St. Salvator Krankenhaus, Halberstadt; Dr. med. M. Thobaben, Universitätskrankenhaus Eppendorf, Hamburg; Dr. med. U. Thiede, Klinikum Nord/HH-Heidberg, Hamburg; Dr. med. N. Geier, Klinikum Heilbronn GmbH, Heilbronn; Dr. med. Hans G. Limbach, Universitätsklinikum des Saarlandes, Homburg/Saar; Fr. Dr. med. E. Bungert, Westpfalz Klinikum, Kaiserslautern; Dr. med. D. Faas, Städtisches Klinikum Karlsruhe gGmbH, Karlsruhe; Dr. med. H. Schröder, Universitätsklinikum Kiel, Kiel, Dr. med. C. Andree, Dr. med. P. Heister, Klinikum Krefeld, Krefeld; Dr. med. T. Werner, Dr. med. M. Streitberg, Klinikum des Landkreises Lörrach, Lörrach; Dr. med. M. Kohl, Universitätsklinikum Schleswig- Holstein, Lübeck; Dr. med. H. Frenzke, Märkische Kliniken GmbH, Lüdenscheid; PD Dr. med. J. Sonntag, Städtisches Klinikum, Lüneburg; Dr. med. V. Aumann, Universitätsklinikum, Magdeburg; Dr. med. S. Bastuck, SHG- Kliniken Merzig, Merzig; Dr. med. K. Kurnik, Dr. med. C. Bidlingmaier, Dr. von Haunersches Kinderspital, München; Dr. J.A. Harding, Klinikum Dritter Orden Nymphenburg, München; Prof. Dr. med. U. Nowak-Göttl, Universitätsklinikum, Münster; Dr. med. B. Kinder, Fr. Dr. med. K. Manzke, Dietrich- Bonhoeffer- Klinikum, Neubrandenburg; Fr. Dr. med. C. Bergheim, Dr. med. E. Jung, Kinderklinik Kohlhof, Neunkirchen; Dr. med. F. Küchel, Kinderklinik Neustadt am Rübenberge, Neustadt a. R.; Dr. med. B. Voigt, Klinikum Offenbach, Offenbach, Dr. med. M. Viemann, Elisabeth Kinderkrankenhaus, Oldenburg; Prof. D. Radke, Ernst von Bergmann Klinikum, Potsdam; Dr. med. B. Zimmermann, Dr. med. C. Hein, Universitätsklinikum Rostock, Rostock; Dr. L. Hempel, Thüringen- Kliniken "Georgius Agricola", Saalfeld; Dr. med. R. Geib-König, Klinikum Winterberg, Saarbrücken; Dr. med. S. Röll, Dr. med. H. Orth, St. Elisabeth Klinik, Saarlouis; Dipl. Med. B. Schenk, Helios Klinikum, Schwerin; Dr. med. Z. Uyanik, Städtisches Klinikum, Solingen; Dr. med. R. Berg, Olgahospital, Stuttgart; Dr. med. T. Trips, Klinikum Traunstein, Traunstein; Dr. med. C. Block, Mutterhaus der Borromäerinnen, Trier; Dr. med. M. Kumpf, Dr. A. Bosk, Universitätsklinikum Tübingen, Tübingen; Dr. H. Vielhaber Klinikum Weiden, Weiden in der Oberpfalz; Dr. med. M. Heldmann, Helios Klinikum Barmen, Wuppertal.

\section{Author details}

${ }^{1}$ Monash Newborn, Monash Medical Centre; The Ritchie Centre, Monash Institute for Medical Research and Department of Pediatrics, Monash University, 246 Clayton RD, Clayton 3168, Melbourne, Australia. ${ }^{2}$ Department of Pediatrics, J.W. Goethe University Hospital, Theodor Stern Kai 7, 60590 Frankfurt/Main, Germany. ${ }^{3}$ Department of Pediatric Cardiology and Pediatric Intensive Care, University Childrens Hospital Hannover, Carl Neuberg Str. 1, 30625 Hannover, Germany. ${ }^{4}$ Baxter BioScience, EdisonStr. 4, 85716 
Unterschleißheim, Germany. ${ }^{5}$ Department of Medical Informatics, Biometry, and Epidemiology, L. Maximilian University, Marchioninistr. 15, 81377 Munich, Germany.

\section{Authors' contributions}

AV was involved in study design, data analysis and interpretation, and writing of the manuscript. DF, MS and FW were involved in data analysis and interpretation, and writing of the manuscript. WK was involved in study design and data analysis. BE was involved in study design and data collection. UM was involved in data management, statistical analysis and data interpretation. RS was involved in study design, data analysis, and writing of the manuscript. All authors read and approved the final manuscript.

\section{Competing interests}

AV was a member of a Baxter advisory board and received as such an honorarium. At the time the study was performed, RS and BE were employees of Baxter Deutschland GmbH, Heidelberg, Germany. All authors had full and unrestricted access to the dataset. Baxter had no influence on the data selection, interpretation or publication.

Received: 21 April 2010 Revised: 15 July 2010

Accepted: 19 August 2010 Published: 19 August 2010

\section{References}

1. Dreyfus M, Magny JF, Bridey F, Schwarz HP, Planche C, Dehan M, Tchernia G: Treatment of homozygous protein $C$ deficiency and neonatal purpura fulminans with a purified protein C concentrate. N Engl I Med 1991, 325:1565-1568

2. Baker PM, Keeling DM, Murphy M: Plasma exchange as a source of protein C for acute-onset protein C pathway failure. Br J Haematol 2003, 120:167-168

3. White B, Livingstone W, Murphy C, Hodgson A, Rafferty M, Smith OP: An open-label study of the role of adjuvant hemostatic support with protein $\mathrm{C}$ replacement therapy in purpura fulminans-associated meningococcemia. Blood 2000, 96:3719-3724.

4. Ettingshausen CE, Veldmann A, Beeg T, Schneider W, Jager G, Kreuz W: Replacement therapy with protein $C$ concentrate in infants and adolescents with meningococcal sepsis and purpura fulminans. Semin Thromb Hemost 1999, 25:537-541.

5. Vincent JL, Nadel S, Kutsogiannis DJ, Gibney RT, Yan SB, Wyss VL, Bailey JE, Mitchell CL, Sarwat S, Shinall SM, Janes JM: Drotrecogin alfa (activated) in patients with severe sepsis presenting with purpura fulminans, meningitis, or meningococcal disease: a retrospective analysis of patients enrolled in recent clinical studies. Crit Care 2005, 9:R331-343.

6. de Kleijn ED, de Groot R, Hack CE, Mulder PG, Engl W, Moritz B, Joosten KF, Hazelzet JA: Activation of protein $C$ following infusion of protein $C$ concentrate in children with severe meningococcal sepsis and purpura fulminans: a randomized, double-blinded, placebo-controlled, dosefinding study. Crit Care Med 2003, 31:1839-1847

7. Kisiel W, Canfield WM, Ericsson LH, Davie EW: Anticoagulant properties of bovine plasma protein C following activation by thrombin. Biochemistry 1977, 16:5824-5831.

8. Joyce DE, Gelbert L, Ciaccia A, DeHoff B, Grinnell BW: Gene expression profile of antithrombotic protein $\mathrm{C}$ defines new mechanisms modulating inflammation and apoptosis. J Biol Chem 2001, 276:11199-11203.

9. Cheng T, Liu D, Griffin JH, Fernandez JA, Castellino F, Rosen ED, Fukudome K, Zlokovic BV: Activated protein C blocks p53-mediated apoptosis in ischemic human brain endothelium and is neuroprotective. Nat Med 2003, 9:338-342.

10. Riewald M, Petrovan RJ, Donner A, Mueller BM, Ruf W: Activation of endothelial cell protease activated receptor 1 by the protein $C$ pathway. Science 2002, 296:1880-1882.

11. Booy R, Habibi P, Nadel S, de Munter C, Britto J, Morrison A, Levin M: Reduction in case fatality rate from meningococcal disease associated with improved healthcare delivery. Arch Dis Child 2001, 85:386-390.

12. Maat M, Buysse CM, Emonts M, Spanjaard L, Joosten KF, de Groot R, Hazelzet JA: Improved survival of children with sepsis and purpura: effects of age, gender, and era. Crit Care 2007, 11:R112.
13. Gurgey A, Aytac S, Kanra G, Secmeer G, Ceyhan M, Altay C: Outcome in children with purpura fulminans: report on 16 patients. Am J Hematol 2005, 80:20-25.

14. Wheeler JS, Anderson BJ, De Chalain TM: Surgical interventions in children with meningococcal purpura fulminans-a review of 117 procedures in 21 children. J Pediatr Surg 2003, 38:597-603.

15. Buysse CM, Oranje AP, Zuidema E, Hazelzet JA, Hop WC, Diepstraten AF, Joosten KF: Long-term skin scarring and orthopaedic sequelae in survivors of meningococcal septic shock. Arch Dis Child 2009, 94:381-386.

16. Hassan Z, Mullins RF, Friedman BC, Shaver JR, Alam B, Mian MA: Purpura fulminans: a case series managed at a regional burn center. J Burn Care Res 2008, 29:411-415.

17. Fischer D, Schloesser RL, Nold-Petry CA, Nold MF, Veldman A: Protein C concentrate in preterm neonates with sepsis. Acta Paediatr 2009, 98:1526-1529.

18. Kreuz W, Veldman A, Escuriola-Ettingshausen C, Schneider W, Beeg T: Protein-C concentrate for meningococcal purpura fulminans. Lancet 1998, 351:986-987, author reply 988

19. Hodgson A, Ryan T, Moriarty J, Mellotte G, Murphy C, Smith OP: Plasma exchange as a source of protein $C$ for acute onset protein $C$ pathway failure. Br J Haematol 2002, 116:905-908.

20. Nadel S, Goldstein B, Williams MD, Dalton H, Peters M, Macias WL, AbdAllah SA, Levy H, Angle R, Wang D, Sundin DP, Giroir B, REsearching severe Sepsis and Organ dysfunction in children: Drotrecogin alfa (activated) in children with severe sepsis: a multicentre phase III randomised controlled trial a gLobal perspective (RESOLVE) study group. Lancet 2007 369:836-843

21. Venkataseshan S, Dutta S, Ahluwalia J, Narang A: Low plasma protein C values predict mortality in low birth weight neonates with septicemia. Pediatr Infect Dis J 2007, 26:684-688,

22. Ernst FR, Johnston JA, Pulgar S, He J, Ball DE, Young JK, Cooper LM: Timing of drotrecogin alfa (activated) initiation in treatment of severe sepsis: a database cohort study of hospital mortality, length of stay, and costs. Curr Med Res Opin 2007, 23:235-244.

23. Wheeler A, Steingrub J, Schmidt GA, Sanchez P, Jacobi J, Linde-Zwirble W Bates B, Qualy RL, Woodward B, Zeckel M: A retrospective observational study of drotrecogin alfa (activated) in adults with severe sepsis: comparison with a controlled clinical trial. Crit Care Med 2008, 36:14-23.

\section{doi:10.1186/cc9226}

Cite this article as: Veldman et al: Human protein C concentrate in the treatment of purpura fulminans: a retrospective analysis of safety and outcome in 94 pediatric patients. Critical Care 2010 14:R156.

\section{Submit your next manuscript to BioMed Central and take full advantage of:}

- Convenient online submission

- Thorough peer review

- No space constraints or color figure charges

- Immediate publication on acceptance

- Inclusion in PubMed, CAS, Scopus and Google Scholar

- Research which is freely available for redistribution

Submit your manuscript at www biomedcentral com/submit
C Biomed Central 